\title{
PERBEDAAN SEKRESI SALIVA, AMBANG KECAP, TEKANAN DARAH, KADAR GLUKOSA DARAH PADA WANITA PEROKOK DAN NON-PEROKOK
}

\author{
Sri Tjahajawati ${ }^{1}$, Anggun Rafisa ${ }^{2}$, Nani Murniati ${ }^{3}$ dan Cucu Zubaedah $^{4)}$ \\ ${ }^{123}$ Departemen Oral Biologi FKG Unpad \\ ${ }^{4}$ Departemen Ilmu Kedokteran Gigi Masyarakat FKG Unpad \\ E-mail: sri.tjahajawati@fkg.unpad.ac.id
}

\begin{abstract}
ABSTRAK. Panas asap rokok dan kandungan berbahaya dalam rokok dapat berdampak pada kesehatan rongga mulut dan sistemik. Pada saat ini jumlah wanita perokok semakin meningkat. Penelitian ini bertujuan untuk membandingkan sekresi saliva, ambang kecap, tekanan darah dan glukosa darah pada wanita perokok dan non-perokok. Penelitian ini termasuk jenis analitik komparatif dengan rancangan komparatif cross-sectional, yaitu membandingkan beberapa outcome kedua kelompok wanita. Data penelitian dianalisis dengan uji Mann-Whitney. Hasil penelitian menunjukan lama merokok rata-rata 4,4 tahun, jumlah rokok yang dihisap 14,8 batang per hari. Usia rata-rata wanita perokok 21,2 tahun. Ambang kecap manis dan asin rata-rata pada wanita perokok lebih tinggi dari wanita nonperokok. Volume dan $\mathrm{pH}$ saliva rata-rata perokok lebih rendah dari wanita non-perokok. Nilai tekanan darah diastolik dan kadar glukosa darah rata-rata pada wanita perokok lebih tinggi dari wanita non-perokok. Ambang kecap manis, tekanan darah sistolik dan kadar glukosa darah antara wanita perokok dan non-perokok berbeda signifikan $(\mathrm{p}<0,005)$. Simpulan penelitian adalah terdapat perbedaan ambang kecap manis, tekanan darah sistol dan kadar glukosa darah pada wanita perokok dan non-perokok.
\end{abstract}

Kata kunci: wanita perokok; sekresi saliva; ambang kecap manis dan asin; tekanan darah, glukosa darah

ABSTRACT. The heat of cigarette smoke and its harmful content can affect oral health and systemic. The number of female smokers has increased dramatically. The research aimed to compare salivary secretion, taste threshold, blood pressure and blood glucose in female smokers and non-smokers. This study was an analytical comparative with cross sectional design. The data was analyzed by the MannWhitney test. The result showed that the average of duration of smoking was 4.4 years, the number of cigarette consumption was 14.8 per day, the average age of female smokers was 21.2 years. The average of sweet and salt taste threshold in female smokers were higher than non-smokers. The average of volume and $\mathrm{pH}$ saliva of female smokers were lower than non-smokers. The average values of diastolic blood pressure and blood glucose levels in female smokers were higher than non-smokers. Sweet taste threshold, systolic blood pressure and blood glucose levels between female smokers and non-smokers were significantly different $(p<0.005)$. It can be concluded that there are the differences in sweet taste threshold, systolic blood pressure and blood glucose levels in female smokers and non-smokers.

Key words: female smokers; salivary secretions; the threshold of sweet and salty; blood pressure, blood glucose.

\section{PENDAHULUAN}

Rongga mulut dianggap cermin kesehatan umum seseorang. Lidah merupakan salah satu organ di rongga mulut yang paling peka terhadap perubahan yang terjadi di dalam tubuh. Pada dasarnya, permukaan lidah adalah daerah yang paling banyak terpapar oleh iritasi dan keperluan dasar hidup sehari-hari seperti makan dan minum.

Hampir satu juta milyar laki-laki di dunia merokok, sekitar 35\% dari mereka berada di Negara maju dan 50\% berada di Negara berkembang. Sekitar 250 juta perempuan di dunia merupakan perokok. Sekitar 22\% dari perempuan tersebut berada di Negara maju dan 9\% berada di Negara berkembang. Rendahnya tingkat konsumsi tembakau pada perempuan di seluruh dunia tidak mencerminkan kesadaran akan kesehatan namun lebih kepada tradisi sosial dan rendahnya sumber ekonomi pada perempuan. Jumlah perokok di dunia akan terus bertambah terutama karena terjadi pertambahan jumlah populasi. Pada tahun 2030 akan ada sekitar 2 milyar orang di dunia. Meskipun angka prevalensi ini salah, jumlah perokok akan tetap meningkat. Konsumsi tembakau telah mencapai proporsi epidemic global (Mackay \& Eriksen, 2002)

Indonesia adalah salah satu Negara konsumen tembakau terbesar di dunia. Indonesia merupakan Negara dengan jumlah konsumsi rokok ketiga tertinggi di dunia setelah Cina dan India (Tribunnews, 2013). Prevalensi penduduk berumur 15 tahun ke atas yang mempunyai kebiasaan merokok berdasarkan Riskesdas tahun 2010 adalah sebanyak 28,2\%. Prevalensi perokok lebih banyak ditemukan pada laki-laki dewasa yang sudah menikah dengan pendidikan dan penghasilan rendah. Menurut profesinya, perokok lebih banyak ditemukan pada petani/ nelayan/buruh (Linelejan, 2012).

Kebiasaan merokok berkaitan erat dengan gaya hidup berkembang di masyarakat. Penyebab dari tingginya konsumsi rokok di Indonesia diakibatkan karena harga rokok yang murah dan kemudahan untuk mendapatkan rokok itu sendiri juga menjadi penyebab tingginya angka konsumsi rokok di Indonesia. Rokok yang beredar di Indonesia antara lain rokok kretek, lintingan, cerutu, rokok putih. Berdasarkan penggunaan filter, rokok dibedakan menjadi rokok berfilter dan rokok non filter. Rokok kretek berfilter lebih sering dikonsumsi daripada rokok kretek tidak berfilter. Filter pada rokok berfungsi untuk mengurangi kadar tar dan nikotin (Geiss, 2007).

Rokok mengandung setidaknya 7000 zat kimia beracun dan bersifat karsinogenik. Zat-zat tersebut menyebabkan berbagai efek negatif bagi rongga mulut dan sistem dalam tubuh lainnya (Benjamin,2010). Efek yang sering tidak disadari oleh perokok adalah berkurangnya kemampuan mengecap. Perubahan fisiologis dapat terjadi 
dalam rongga mulut akibat rokok misalnya mukosa mulut menjadi kering, menurunnya aliran saliva, rentan terhadap iritasi, atrisi gigi, dan atrofi otot penguyahan (Hasibun, 1998). Manusia dewasa normal memiliki indra pengecap sebanyak 3.000 sampai 10.000 putik kecap yang terus beregenerasi, sedangkan usia diatas 45 tahun putik kecap mengalami degenerasi sehingga menyebabkan sensasi pengecapan yang kurang sensitif (Guyton \& Hall, 2010). Bahaya rokok memang dapat menyerang kepada siapa saja, namun risiko terbesar dari merokok lebih mengancam para wanita. Perokok wanita berisiko 25 persen lebih tinggi daripada perokok pria. Perokok wanita memiliki risiko ganda terhadap penyakit jantung dan kanker paru-paru bila dibandingkan dengan perokok pria. Penyebabnya karena wanita memiliki berat badan dan saluran darah yang lebih kecil dari pria. Bahaya merokok pada wanita antara lain: Merusak kulit, mengganggu sistem reproduksi, mengganggu siklus menstruasi termasuk timbulnya rasa nyeri, menurunkan kesuburan, meningkatkan risiko terkena kanker payudara, rahim, rongga mulut, dan kanker paru-paru, mengganggu pertumbuhan janin dalam rahim, mengganggu kelancaran ASI, keguguran, hingga kematian janin.

Penurunan fungsi pengecapan berpengaruh pertama kali pada fungsi pengecapan rasa manis dan rasa asin (Fehrebach, 2015; Hoyer \& Roodin, 2003). Pengecapan rasa manis merupakan pengindraan beberapa zat kimia organik seperti gula, sedangkan rasa asin pengindraan dari zat garam yang diterima oleh putik kecap dalam rongga mulut. Rasa manis dan asin bisa didapatkan dari bermacam-macam bahan makanan. Rasa manis yang umum ditemukan dalam makanan berasal dari sukrosa (gula) dan rasa asin ditemukan dari garam dapur (Wasito,2014).

Gula dan garam selain menciptakan selera makan, juga berperan sebagai kebutuhan nutrisi tubuh. Asupan gula dalam satu hari tidak lebih dari 50 gram, sedangkan masyarakat Indonesia cenderung mengonsumsi gula $4 \mathrm{x}$ lebih banyak (Anthonie,2015). Asupan garam di negaranegara Asia adalah sekitar 9 gram sampai 12 gram yang lebih dari dua kali lipat dari rekomendasi World Health Organization (WHO). Konsumsi gula dan garam dapat dipengaruhi oleh fungsi pengecapan, apabila terjadi penurunan pada fungsi pengecapan maka konsumsi gula dan garam tidak akan terkontrol (Chau et al., 2015).

Penuruan fungsi pengecapan pada jaringan lunak dapat menyebabkan sensitivitas pengecapan menurun sehingga akan memengaruhi nafsu makan. Menurunnya nafsu makan dapat memengaruhi asupan nutrisi, apabila kekurangan asupan nutrisi akan menjadi kelompok yang rentan penyakin (Freedman, 1979; Sunariani et al., 2007). Penurunan sensitivitas pengecapan rasa manis dan asin secara alamiah tidak akan mengancam kelangsungan hidup dengan cepat, namun dapat memberikan pengaruh yang besar terhadap kualitas hidup (Ship,2002).

Asap panas dan nikotin dalam rokok merupakan kandungan rokok yang paling berpengaruh terhadap kemampuan mengecap. Udara panas dari rokok dapat mengakibatkan papilla lidah menjadi datar. Kadar nikotin yang tinggi pada rokok mengiritasi kuncup pengecap dan mengganggu impuls saraf ke otak, dan memengaruhi sekresi saliva sehingga dapat mengakibatkan berkurangnya sensasi lidah terhadap rasa (Eskolin, 2005). Peningkatan kemampuan mengecap dirasakan oleh individu yang telah berhenti merokok. Kemampuan mengecap rasa manis manusia terdapat pada ujung lidah. Pada seorang perokok, asap rokok yang dihisap dapat langsung mengenai ujung lidah. Hal ini dapat secara langsung memengaruhi kemampuan pengecapan rasa manis yang berakibat meningkatnya ambang rasa manis. Ambang kecap rasa manis sukrosa pada manusia adalah $0.01 \mathrm{M}$. Lama merokok dan jumlah rokok yang dikonsumsi per hari juga memengaruhi ambang rasa pada perokok, semakin lama kebiasaan merokok, rokok yang dikonsumsi maka semakin tinggi pula ambang rasa manis perokok tersebut (Eskolin,2005).

Peningkatan konsumsi gula dan garam dapat terjadi pada seseorang yang mengalami peningkatan ambang rasa manis maupun asin, hal ini berkaitan dengan meningkatnya resiko diabetes dan hipertensi. Akibat lain yang ditimbulkan dari peningkatan ambang rasa pada lidah perokok adalah berkurangnya kemampuan mengecap, hal ini akan mengakibatkan berkurangnya nafsu makan perokok. Perokok yang mengalami penurunan nafsu makan lama kelamaan akan mengalami malnutrisi. Hal ini juga dapat memengaruhi kualitas hidup seseorang terutama pada kelompok wanita dapat berdampak pada generasi penerusnya.

Penelitian awal yang melibatkan mahasiswa telah dilakukan pada sekelompok lanjut usia dan dewasa muda dengan hasil terdapat perbedaan nilai ambang kecap manis dan asin pada kelompok lanjut usia dan kelompok dewasa muda, nilai ambang kecap manis dan asin pada kelompok lanjut usia lebih tinggi dari kelompok dewasa muda. Penelitian lain dilakukan pada kelompok buruh perekok kretek filter didapatkan nilai ambang kecap manis yang lebih tinggi dari kelompok bukan perokok. Pada tahap awal proses inisiasi, saliva akan melarutkan substansi makanan sehingga substansi ini bersama aliran saliva akan memasuki daerah reseptor pengecapan (Tjahajawati, 2012). Pemeriksaan lain yang akan dilakukan adalah pengukuran kadar glukosa darah dan tekanan darah yang dapat dihubungkan dengan peningkatan konsumsi gula dan garam akibat ambang kecap yang meningkat sehingga dapat menimbulkan penyakit seperti diabetes mellitus dan hipertensi.

Berdasarkan uraian latar belakang di atas, maka perlu dilakukan penelitian untuk melihat perbandingan antara sekresi saliva, ambang kecap, tekanan darah dan glukosa darah pada wanita perokok dan non-perokok. Uraian keterkaitan riset dengan pengabdian adalah pembekalan pengetahuan yang merupakan pengetahuan tambahan bagi mahasiswa Unpad khususnya dan masyarakat umumnya, untuk lebih memahami dampak rokok pada kesehatan rongga mulut dan sistemik. 


\section{METODE}

Penelitian ini termasuk jenis analitik komparatif dengan rancangan komparatif cross-sectional, yaitu membandingkan beberapa outcome kedua kelompok wanita. Penelitian dilakukan setelah mendapatkan persetujuan etik dari Komite Etik dan informed consent dari responden.

Data yang dikumpulkan dalam penelitian dibantu mahasiswa yang terlibat dalam KKN dengan melakukan kalibrasi pengukuran dan tata cara terlebih dahulu. Variabel yang diukur terdiri dari:

\section{Karakteristik responden}

Responden diberikan kuesioner untuk mengetahui usia, status merokok (perokok/tidak), jangka waktu merokok, jumlah rokok per hari dan kesediaan untuk ikut serta dalam penelitian.

2. Pengukuran nilai ambang kecap manis dan asin Nilai ambang kecap ditentukan ketika subjek dapat memastikan rasa. Skala yang digunakan dengan skala interval dari konsentrasi terendah hingga tertinggi yaitu $0.005 \mathrm{M}, 0.01 \mathrm{M}, 0.015 \mathrm{M}, 0.02 \mathrm{M}, 0.025 \mathrm{M}, 0.03 \mathrm{M}$, $0.035 \mathrm{M}, 0.04 \mathrm{M}, 0.045 \mathrm{M}, 0.05 \mathrm{M}$.

3. Sekresi saliva ( $\mathrm{pH}$ dan volume)

Volume Saliva dikumpulkan selama lima menit untuk mengukur berapa banyak saliva yang dihasilkan. Nilai $\mathrm{pH}$ saliva didapatkan dengan meletakkan $\mathrm{pH}$ paper test di bawah lidah selama 2 menit, selanjutnya perubahan warna pada $\mathrm{pH}$ paper test disesuaikan dengan indikator.

4. Nilai tekanan darah

Tekanan darah sistolik dan diastolik diukur menggunakan sphygmomanometer dan stetoskop dengan metode kombinasi.

5. Kadar glukosa darah

Kadar glukosa diukur menggunakan alat glukometer.

\section{HASIL DAN PEMBAHASAN}

Jumlah responden yang diperoleh pada penelitian ini terdiri dari 24 orang wanita perokok dan 49 orang wanita yang tidak merokok. Usia responden berkisar antara 18 sampai 24 tahun, dengan rata-rata usia 21,2 tahun (SD 1,5 tahun). Karakteristik responden wanita perokok yaitu berusia antara 19 sampai 24 tahun dengan pendidikan terakhir SMA. Durasi merokok rata-rata 4,41 tahun dan menghisap 14,8 batang rokok per harinya.

Tabel 1. Hasil data karakteristik responden wanita perokok

\begin{tabular}{cc}
\hline Karakteristik responden wanita perokok & Rata-rata \\
\hline Usia (tahun) & 21,25 \\
Durasi merokok (tahun) & 4,41 \\
Jumlah rokok per hari (batang) & 14,8 \\
Pendidikan terakhir & SMA \\
\hline
\end{tabular}

Hasil rata-rata pengukuran variabel yang diteliti ditampilkan pada diagram 1 sampai 4. Sensitivitas ambang kecap rata-rata pada wanita perokok untuk ambang kecap manis lebih rendah dibandingkan dengan wanita non-perokok, namun untuk ambang kecap asin memiliki sensitivitas rata-rata yang sama antara wanita perokok maupun non-perokok. Volume dan $\mathrm{pH}$ saliva ratarata pada wanita non-perokok lebih tinggi dibandingkan wanita perokok. Hasil pengukuran tekanan darah rata-rata pada wanita perokok dan non-perokok menunjukan bahwa tekanan darah sistol maupun diastol lebih tinggi pada wanita perokok. Hasil pengukuran kadar glukosa darah rata-rata menunjukkan wanita non-perokok memiliki nilai kadar glukosa darah yang lebih rendah dibanding wanita yang merokok.

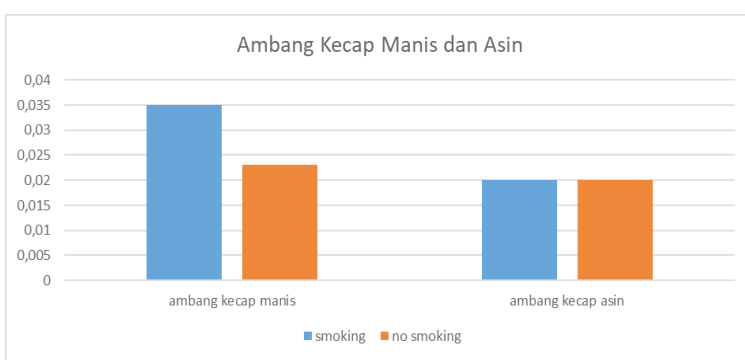

Gambar 1. Hasil pengukuran ambang kecap

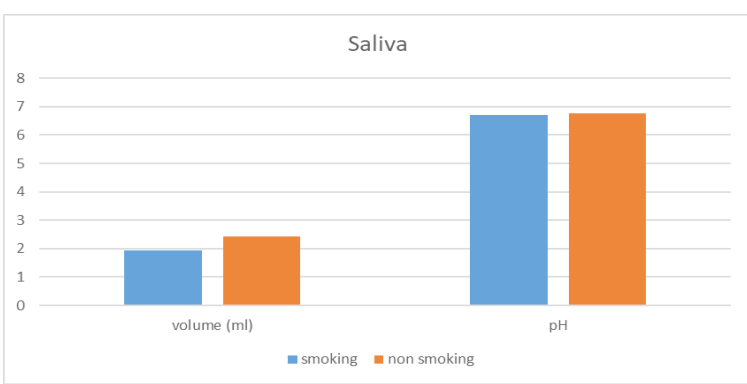

Gambar 2. Hasil pengukuran saliva

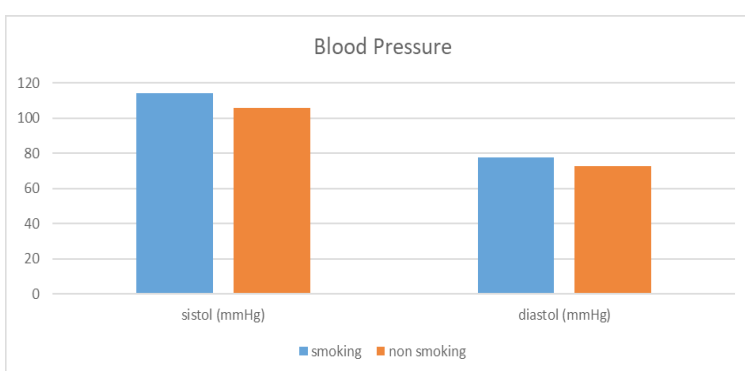

Gambar 3. Hasil pengukuran tekanan darah

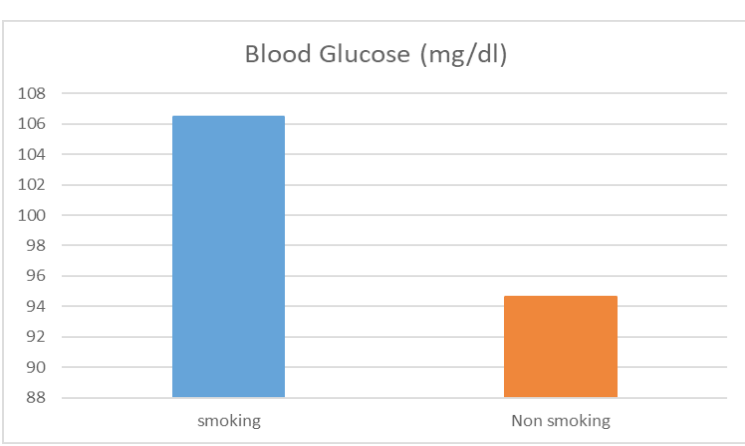

Gambar 4. Hasil pengukuran kadar glukosa darah 
Hasil pengukuran terhadap variabel-variabel yang telah diteliti tersebut kemudian diuji perbedaannya menggunakan uji Mann-Whitney. Tabel 2. Menunjukkan perbandingan sensitivitas ambang kecap, sekresi saliva, tekanan darah dan kadar glukosa darah pada wanita perokok dan non-perokok. Ambang kecap manis, tekanan darah sistolik dan kadar glukosa darah antara wanita perokok dan non-perokok memiliki perbedaan yang signifikan $(p<0,005)$, sedangkan variabel lain tidak menunjukkan perbedaan yang signifikan.

Tabel 2. Perbandingan sensitivitas ambang jecap, sekresi saliva, tekanan darah dan kadar glukosa pada wanita merokok dan non-perokok

\begin{tabular}{|c|c|c|c|}
\hline \multirow[b]{2}{*}{ Variabel } & \multicolumn{2}{|c|}{ Status wanita merokok } & \multirow[b]{2}{*}{ Nilai $\mathbf{p}^{* *}$} \\
\hline & $\underset{(n=24)}{Y a}$ & $\begin{array}{c}\text { Tidak } \\
(n=49)\end{array}$ & \\
\hline Sweet taste & $\begin{array}{c}\left.0,037^{*}\right) \\
(0,015- \\
0,050)\end{array}$ & $\begin{array}{c}0,020 \\
(0,005- \\
0,050)\end{array}$ & $<0,001$ \\
\hline Salt taste & $\begin{array}{c}0,020 \\
(0,010- \\
0,035)\end{array}$ & $\begin{array}{c}0,020 \\
(0,005- \\
0,050)\end{array}$ & 0,611 \\
\hline Volume saliva & $\begin{array}{c}2 \\
(1-4)\end{array}$ & $\begin{array}{c}2 \\
(1-8)\end{array}$ & 0,157 \\
\hline $\mathrm{pH}$ saliva & $\begin{array}{c}7 \\
(5-7)\end{array}$ & $\begin{array}{c}7 \\
(6-7,5)\end{array}$ & 0,664 \\
\hline Sistolik (mmHg) & $\begin{array}{c}\left.110^{*}\right) \\
(100-140)\end{array}$ & $\begin{array}{c}100 \\
(90-120)\end{array}$ & $<0,001$ \\
\hline Diastolik (mmHg) & $\begin{array}{c}80 \\
(60-100)\end{array}$ & $\begin{array}{c}70 \\
(60-90)\end{array}$ & 0,005 \\
\hline Kadar Glukosa & $\begin{array}{c}114 \\
(77-128)\end{array}$ & $\begin{array}{c}90 \\
(76-144)\end{array}$ & $<0,001$ \\
\hline
\end{tabular}

Merokok adalah salah satu fenomena abad kedua puluh ini, walaupun sudah ada sejak berabad-abad yang lalu. Keinginan merokok pada wanita lebih besar dibandingkan dengan pria karena wanita lebih cepat merasa gelisah dan wanita merasa dengan merokok akan terlihat lebih kekinian, serta ada pendapat bahwa dengan merokok dapat menjaga tubuh tetap langsing (Lubis, 1994). Jumlah perokok wanita setiap tahun meningkat dari $4,2 \%$ pada tahun 1995 menjadi 6,7\% pada pada tahun 2013 atau dari setiap 100 orang perempuan Indonesia 7 orang diantaranya perokok (Biro komunikasi dan pelayanan masyarakat, 2016). Wanita menganggap merokok merupakan symbol modernisasi sehingga mereka mengabaikan dampak buruk yang dapat diakibatkan oleh asap panas rokok maupun kandungan berbahaya di dalam rokok seperti nikotin. Pengaruh rokok pada wanita berbeda dengan pria karena terdapat perbedaan siklus hormonal antara wanita dan pria seperti menstruasi, kehamilan, dan menopause.

Usia perokok rata-rata 21 tahun merupakan usia dewasa muda, perilaku merokok pada usia ini berdasarkan penghasilan dan lingkungan pergaulan. Semakin bertambahnya usia, maka semakin banyak pula tuntutan dari lingkungan sosial di sekitarnya. Ini membuat orang harus dapat menyesuaikan diri terhadap lingkungannya. Jika individu dapat memandang dirinya berbeda dengan orang lain dan dapat menyesuaikan diri dengan lingkungan, mereka akan siap memasuki faktor lingkungan sosial yang bersifat negatif tanpa harus terpengaruh oleh pergaulan yang bersifat negative (Mutadin, 2004).

Penurunan fungsi saliva dapat mengakibatkan rongga mulut menjadi kering. Hal ini merupakan efek jangka panjang asap panas rokok dan kandungannya terhadap kelenjar saliva. Penurunan laju aliran saliva dapat meningkatkan angka kejadian mulut kering dan penurunan $\mathrm{pH}$ pada perokok, jika berlangsung terus menerus dapat menyebabkan serostomia. Penurunan laju aliran saliva menurunkan fungsi saliva sebagai lubrikan, cleansing, zat pertahanan tubuh terganggu. Hal ini dapat memengaruhi status kesehatan dan kebersihan gigi dan rongga mulut (Vellappally, et al, 2007).

Nilai ambang kecap manis dan asin pada kelompok wanitaperokok cenderung lebih tinggi dibandingkelompok non-perokok, akibat hal ini dapat meningkatkan konsumsi gula dan garam. Efek langsung secara berkesinambungan adalah terjadi peningkatan kadar glukosa darah dan tekanan darah. Hasil pemeriksaan menunjukan kadar glukosa darah wanita perokok lebih tinggi dari nonperokok, demikian pula untuk tekanan darah sistolik dan diastolik. Keadaan ini apabila tidak diwaspadai dapat menganggu kesehatan tubuh secara umumnya dan dapat menurunkan kualitas hidup wanita yang menjadi calon ibu bagi generasi penerus bangsa.

\section{SIMPULAN}

Simpulan dari penelitian ini adalah terdapat perbedaan ambang kecap manis, tekanan darah sistol dan kadar glukosa darah pada wanita perokok dan non-perokok.

\section{UCAPAN TERIMAKASIH}

Peneliti mengucapkan terimakasih kepada Rektor, Direktur DRPMI dan Dekan FKG atas dana internal Riset Fundamental yang diberikan.

\section{DAFTAR PUSTAKA}

Benjamin, R. M. (2010). How Tobacco Smoke Causes Disease. USA: U.S Departement of Health and Human Services. 2-7 pp.

Chau, P. H., Leung, Chan, et al. (2015). Development and Validation of Chinese Health Literacy Scale for Low Salt Consumption. Hong Kong Population Vol 10(7), 1-15.

Eskolin, T. (2005). Changes in gustatory performance. The effects of smoking on sensing the five primary taste qualities and water. [Online]. Available at suomenakatemia.fi (diakses 23 Mei 2014) 
Fehrebach, M. J. (2015). Aging of oral mucosa. Does my mouth show my age, Vol 35(3), p73-84. 12p.

Freedman, K. A. (1979). Management of the Geriatric Dental Patient. Chicago: Quintessence Publ. Co, Inc. Hal 15-22.

Geiss, O, D. K. (2007). Tobacco, Cigarettes and Cigarette Smoke. Luxemburg: Institute for Health and Consumer Protection. 20 pp.

Guyton, A.C.; J. E. Hall. 2010. Textbook of Medical Physiology $10^{\text {th }}$ edition. Philadelphia Berlin: Springer. Hal 830-834.

Hasibuan, S. (1998). Keadaan-keadaan di rongga mulut yang perlu diketahui pada usia lanjut. Majalah Kedokteran Gigi USU, Vol. 4 : 40-3.

Linelejan, F. ( 2012). Gambaran fungsi paru, kebiasaan merokok dan kebiasaan olahraga pada nelayan di kelurahan bitung karangria kecamatan tuminting kota manado. [Online]. Universitas Sam Ratulangi, 1-8. Available at fkm.unsrat.ac.id (diakses $22 \mathrm{Mei}$ 2014).

Mackay J, Eriksen M. (2002). The Tobacco Atlas, WHO.

Mu'tadin, Z. (2002). Kemandirian Sebagai Kebutuhan Psikologi Pada Remaja. www.e-psikologi.com. diakses pada tanggal 8 Maret 2017.
Ship, J. (2002). Dental and oral disorder in the merck manual of geriatrices. [Online]. Available at :http:// www.merck.com/ (diakses 2 September 2015).

Sunariani, J., Yulianti, \& Alfah, B. (2007). Perbedaan Persepsi Pengecap Rasa Asin antara Usia Lanjut dan Usia Subur. Media Majalah Ilmu Faal Indonesia, Vol. 6(3).

Tjahajawati,S. (2010). Analisis ambang nyeri dan kadar Matrix Metalloproteinase (MMP)-8 Gingival Crevicular Fluid sebagai Indikator Keberhasilan Perawatan Hipersensitivitas Dentin Melalui Induksi Iontoforesis Bahan Kalium. Disertasi.

News. (2013). Perokok di indonesia terbanyak ke-3 di dunia. [Online]. Available at: http://www. tribunnews.com/kesehatan/2013/11/11/perokokdi-indonesia-

terbanyak-ke-3-di-dunia (diakses 19 Mei 2014)

Vellapally,S.; Fiala, Z.; Smejkalova,J.;Jacob,V.; \& Shriharsha,P. (2007). Influence of tobacco use in dental caries development. Cent Eur J Public Health 15(3):116-121.

Wasito, R. N. (2014). Hubungan Antara Fungsi Pengecapan Rasa Asin dengan Statuts Tekanan Darah pada Lansia. Yogyakarta: Universitas Gajah Mada. 